\title{
A Comparative Study of the Deep Structure of Culture Reflected in English and Chinese Social Proverbs
}

\author{
Wen Zhao \\ Faculty of English, College of Literature and Law, Sichuan Agricultural University, Ya'an, China
}

\begin{abstract}
Social proverbs contain life philosophies and experience as well as moral standards; aspects of social life are reflected in the mirror of social proverbs. Social proverbs are of both language and culture. Because of their abundant cultural information, social proverbs have been studied from the point of culture in many researches. Although many researches have been done to reveal the cultural similarities and differences between English and Chinese proverbs, they hardly focus on the deep structure of culture reflected or refracted in them. A comparative study on English and Chinese social proverbs, by illustrating their connection with the deep structures, is provided. The differences between the deep structures of Western and Chinese culture can be therefore revealed.
\end{abstract}

Index Terms - The deep structure of culture, Chinese and English social proverbs

\section{INTRODUCTION}

Along with the development of English language education and researches in China, English-Chinese comparison has become a hot spot in linguistic studies. As cultural-bound expressions, idiomatic expressions turned into a popular study object of the comparative studies. However, comparing with other idiomatic expressions especially idioms, proverbs are to some extent neglected. The majority of limited amounts of monographs deal with structural and rhetorical features of English and Chinese proverbs, their teaching and translation, as well as the cultural information contained in them. Although many researches have been done to reveal the cultural similarities and differences between English and Chinese proverbs, they hardly focus on the deep structure of culture reflected or refracted in them.

\section{LITERATURE REVIEW}

\section{A. Definitions of the Proverb}

1. Definitions of the English Proverb

As a master proverb researcher, Archer Taylor used an entire book-his famous classic study Proverbs - to define the proverb, and he finally reached a conclusion proverbial itself:

The definition of a proverb is too difficult to repay the undertaking.... An incommunicable quality tells us this sentence is proverbial and that one is not. Hence no definition will enable us to identify positively a sentence as proverbial...Let us be content with recognition that a proverb is a saying current among the folk.

(qtd. in Mieder, 1989, p. 14)

After conducting a survey by requiring various people of the 1980's living in an industrial and progressive society to write down their definitions of the proverb and studying the frequencies of certain words, Mieder (1989) found that from four to twenty times in the collected definitions appeared the following words: a phrase, saying, truths, morals, experience, lessons, advice concerning life and which has been handed from generation to generation and then he formulated a simple definition of the proverb that "a proverb is a short sentence of wisdom"(p. 15).

Major authoritative English dictionaries all provide definitions of the proverb, which to some extent vary from each other but also share some similarities. According to Webster's Dictionary of the English Language Unabridged (1979), a proverb is a short saying in common use expressing a well-known truth or common fact ascertained by experience or observation; a maxim; an adage. The definition in Longman Modern English Dictionary (1976) gives more details on the content of the proverb, a proverb is a brief familiar maxim of folk wisdom, usually compressed in form, often involving bold image and frequently a jingle that catches the memory.

2. Definitions of the Chinese Proverb

As the most famed and influential linguistic work of ancient China, Shuowen is regarded as a general reference on Chinese linguistic study. In his masterpiece, Xu Shen of Han Dynasty gives a brief definition for the proverb: “谚, 传言 也”. While the so-called “传言”, in Duan Yucai's note, are “古语也, 凡经传所称之浐, 无非前代故训 (maxims handed down from ancestors) ...".

Wen Duanzheng (1985) points out in Proverbs that “浐语在古代典籍常常单称为“浐”或“语”...古人所说的谚语, 是 
指在群众中广泛流传并世代口耳相传的通俗而简练的语言形式 (proverbs in ancient Chinese classics refer to common and pithy language uses popular in the general public and transmitted throughout generations)." (p. 1-4) Also in this book, Wen classifies proverb definitions into two categories: In the broad sense, proverbs are taken as folk adages, which means “流传在人民群众口头上的一切俚偙俗语 (all kinds of folk adages used among common people in their daily talks)” (ibid, p. 4). In the narrow sense, “浐语是以传授知识为目的的俗语 (proverbs are folk adages conveying knowledge)" (ibid).

Chinese authoritative dictionaries also give definitions for the proverb. According to Word-Ocean Dictionary (1979), the proverb is defined as follows: proverbs are short and popular sayings pregnant with profound meanings among the masses, most of which reflect the experience of people's life or their struggles. Modern Chinese Dictionary (1992) defines the proverb as set phrases popular among the masses using simple words to reflect profound wisdom.

\section{B. English and Chinese Proverbs as the Same Linguistic Phenomenon}

Scholars, either abroad or home, work to narrow down the definition of the proverb. The proverb has pushed back its boundary comparing with that in the ancient times. Although many hopes of giving a satisfactory definition of the proverb have been given up, a proverb can still be distinguished by pointing out some of its crucial features. Such an attempt will be based on a close examination of English and Chinese proverbs and a summarization of definitions and sources presented in the preceding parts.

Both English and Chinese proverbs are idiomatic statements on sentence level. "Idiomatic" here refers to the features of semantic unity and structural stability. A proverb functions as an undividable unit and its meaning is not a mere addition of literal meanings of its component words. Applying figurative or metaphor expressions, proverbs carry profound cultural and historical implication. “大鱼吃小鱼, 小鱼吃虾米”, using a metaphor of food chain in the natural world, refracts the hierarchy and power relationship in human society. The form of proverbs is fixed and only slight modification can be tolerated. For instance, the proverb “割鸡焉用牛刀”, with its traceable origin in Analects of Confucius, has undertaken little formal change through thousands of years; only some minor alterations in such characters as “割” can be accepted. A small change "Money makes the mare to go" from its original form "money makes the mare go" may make this proverb odd.

Both English and Chinese proverbs contain profound wisdom. Knowledge ranging from general truths rooted in experience to life philosophy with deep depth features the proverb. For thousands of years, they serve as guidelines to instruct and inspire people. From proverbs such as “早霞有雨晚霞晴” and “nurture is above nature”, people get advice or counsel for their everyday life. Social morality is also reflected in proverbs. Individualism and collectivism held respectively by Western and Chinese cultures are obvious in such proverbs as "pull yourself up by your own boot straps” and “众人拾柴火焰高”.

English and Chinese are similar in their respective sources. Most of English and Chinese proverbs are of folk origin and enjoy wild popularity among the general public; containing folk wisdom and general truths, they are crystallizations of human wisdom and carriers of culture. In Summary of English Proverbs, Zeng Zili (1983) holds that most English proverbs are from the colloquial speech of common people. Wang Dechun et al. (2003) also argue that common people are creators and users of proverbs; only with their acceptance and widespread popularization can an expression become a proverb. English and Chinese proverbs cover almost every aspect of social life; they reflect collective wisdom of the masses. People from all walks of life contribute to the creation, polishing and dissemination of proverbs. Although many proverbs, English and Chinese alike, come from written materials such as religious and literary classics, they acquire their essence as being proverbial by winning the acceptance of common people and getting frequently used in their daily talks. What is more, the true authors of the proverbs with roots from classic works are in doubt; those classics may only preserve, polish and popularize the proverbs, which might have existed and spread by mouths for long time.

The features shared between English and Chinese proverbs which are listed above lay the foundation for this comparative study. Either the English proverb or its Chinese counterpart, as their essential features are all in common, can be to great extent regarded as the same linguistic and cultural phenomena.

\section{Typologies of Proverbs}

The typologies of proverbs, both Chinese and English, like definitions of the proverb, vary from different angles. This paper aims to study proverbs mainly from cultural perspective, so the classification by Wen Duanzheng is adopted. Wen (2005) classifies proverbs into two major categories: Natural proverbs contain experience of production and relevant knowledge about production, e.g. “犁地要深, 耙地要平”. Social proverbs are about social life of people. They can be further categorized into proverbs reflecting philosophical thoughts, e.g. “无风不起浪”, proverbs preserving social experience, e.g. “言多必失”, proverbs serving to strengthen morality, e.g. “宁伸扶人手, 莫开陷人口”. (ibid, p. 36-49)

\section{Social Proverbs Reflecting or Refracting the Deep Structure OF Culture}

Culture in the broad sense, called Culture with a capital "C", is an all-embracing concept; it can refer to both spiritual and material things created by human beings. It is "a system of shared beliefs, values, customs, behaviors, and artifacts 
that the members of a society use to cope with their world and with one another and that are transmitted from generation to generation through learning" (D. G. Bates \& F. Plog, 1990, p. 28).

According to Samovar et al. (2000), the deep structure of culture refers to such issues as the relation between God and man, the individual and the group, among families, as well as differing views of the relative importance of liberty and authority, equality and hierarchy, rights and responsibilities. Those issues together construct the deep structure of culture, which endures for centuries and helps define the certain culture. The deep structure is the core of culture; it is its most essential and stable part.

In the deep structure can each culture find the source for its unique way to view the world. "World view is a culture's orientation toward God, humanity...and other philosophical issues that influence how its members perceive their world." (ibid, p. 88) It deals the questions about the meaning of life and man's existence. The world view originates in the deep structure of culture and lies at the heart of the cultural system. It can influence all aspects of perception. (ibid) World views spread through various channels. Religion is considered by westerners as the predominant way to transmit the world view due to the prevailing religious culture in the West; while in China, the world view take the form of life philosophy, especially those philosophical thoughts from Confucianism, Taoism and Buddhism.

As the central cultural element, the world view consequently affects cultural belief and value systems. Belief systems are people's beliefs to truth; they tell people how the world operates. (ibid, p. 58) Based on belief systems, value systems can be formed. A value can be defined as "an enduring belief that a specific mode of conduct or end-state of existence is personally or socially preferable to another." (Rokeach, 1973, p. 5) A value system is "a learned organization of rules for making choices and for resolving conflicts." (ibid, p. 161) It is a set of criteria to judge behaviour, which represents people's requirements, expectation, and prohibition. Any culture, although with different individual beliefs and values, contains cultural ones permeating the entire milieu. Belief and value systems, together with other patterns including norms, attitudes, etc. of a culture influence its members' perception of reality and finally shape their behaviour - their reaction to the world.

According to Wen (2005), social proverbs mainly comprise those of life philosophy, morality, as well as social experience. World views as well as belief and value systems closely originated from the deep structure of culture can be generally found in social proverbs.

The world view on such issues as God and men, life and death, individual and group, parents and children, equality and hierarchy etc. are straight reflected or indirectly refracted in social proverbs, for example:

God is above all.

生死有命, 富贵在天。

Better bend than break.

好死不如赖活着。

If you want a thing well done, do it yourself.

众人拾柴火焰高。

The sins of the fathers are visited upon the children.

父母之命, 媒妁之言。

Jack is as good as his master.

小鬼斗不过阎罗王。

Originated from the world view, cultural belief and value systems also present themselves in social proverbs to exert their influence on the masses:

God is where he was.

离地三尺有神灵。

Heaven's vengeance is slow but sure.

不是不报时候未到。

Do well and have well.

善有善报，恶有恶报。

多行不义必自曁。

Every one must carry his own cross.

The philosophies or morality contained in social proverbs depending on which men conduct and the society operates lie at the heart of social life; they reveal the deep structure of culture. Comparing with other cultural phenomena, due to their close link with world views as well as cultural beliefs and values, the reflections or refraction in social proverbs are much more obvious.

\section{A Comparative Study OF English ANd Chinese Social Proverbs}

Social proverbs reflect or refract the deep structure of culture, so cultures with different deep structures must have sets of proverbs showing distinctive cultural orientations. The Western and Chinese cultures are notably different. By comparing English and Chinese social proverbs, the dissimilarities of the deep structures between the West and China can be disclosed.

The typology of orientation by Kluckhohns and Strodtbeck for analyzing cultural patterns is applied to the study into 
English and Chinese social proverbs. Kluckhohns and Strodtbeck (1960) make this typology on the basis of the conclusion that the following five conceptions are the paramount concerns of most cultures: the relation between humankind and nature; the character of human nature; the relationship among people; the orientation toward activity; the value placed on time. The human and nature, human relationship, and time orientations dominant in Western and Chinese cultures, which possess obvious distinct features, will be revealed by studying English and Chinese social proverbs. Hofstede's (1991) value dimensions of individualism-collectivism, uncertainty avoidance, power distance, and masculinity and femininity are also used partially in the research.

\section{A. Social Proverbs about the Relationship of Humankind to Nature}

The relation of humankind to nature is an essential problem in every culture. Behind the differences of desire, attitudes, and behaviour among different cultures always hide sharply distinct views towards nature.

1. English Social Proverbs about Humankind's Mastery over Nature

Western culture takes a mechanistic world view towards nature. (Samovar et al., 2000) Westerners consider nature as a physical system operating according to scientific laws, i.e. a mechanism; as a mechanism, nature can be understood, worked on, or even redesigned. To some extent, this mechanic view of nature owes to the Biblical tradition in the West. In Christianity, God creates everything; nature, no matter environment or animal and plant species, is no more than a creature and enjoys no superiority. On the contrary, man are created in the image of God and as the master over other creatures. Human and nature, in Christian tradition dominant in Western culture, do not form an integrated whole but are separated. There is a line drawn clearly between humankind and nature; man is endowed by God with a role superior to nature. Westerners separate themselves from nature and seek to conquer nature. English proverbs "human is the soul of the universe" and "human is the measure of everything" make clear that the human's unique and irreplaceable role over nature and other creatures. The proverb "nature is conquered by obeying her" is another example to illustrate the Western view to nature. From its literal meaning, this proverb warns people to abide by nature, but the verbs "conquer" and "obey" uncover the belief hidden deeply behind of taking nature as an opposite of man. It can be taken as a refraction of the orientation of humankind's mastery over nature.

Influenced by the orientation of humankind's superiority to nature and clinging to the belief in human rationality, westerners suppose that fate can be mastered and think highly of active behaviour. The proverb "God helps those who help themselves" literally put emphasis on the highest role of God as all mighty, but essentially suggests people act actively in their lifetime and not to yield to the destiny. "Every man is the architect of his own fortune" frankly let out the belief that man can shape their life by themselves.

Taken as a mechanism, nature actually becomes an object of humankind's observation and research. This partially contributes to the formation of westerners' dualistic view towards the world. "The West often perceives the world as being composed of separate pieces to be manipulated and examined." (ibid) Therefore, the thought pattern of westerners is analytic and the difference is focused in Western culture. From the proverb "where nothing is, nothing can be had", a dualistic view of "is" or "not-is" is shown obviously.

2. Chinese Social Proverbs about Humankind in Harmony with Nature

The predominant value in Chinese culture is the harmony of humankind with nature, which is called “天人合一” in Chinese. Chinese civilization is based on agriculture; man and nature together form an integrated system. Chinese proverb “百业农为本, 民以食为天” reflects the importance of agriculture to Chinese culture. Chinese people mainly depend on earth to get food; they have to obey laws of nature to survive.

Confucianism, Taoism and Buddhism profoundly affect the deep structure of Chinese culture. Taoism is against the aggressive behaviour to nature and promotes the returning of humankind to nature. Buddhism prevents people from killing. “返璞归真” and “放下屠刀, 立地成佛” respectively reflect Taoist and Buddhist views on life.

Taoism naturalizes man, while Confucianism personifies nature; they both regard nature and man as an interrelated and inseparable entirety. The word "天(sky)" is used in Chinese to refer to nature; it can also mean the way in which nature and society operates or even some concept or existence governs the world. In proverbs such as “天命不可违” and “天无绝人之路”, “天” can be interpreted from the perspectives of both nature and society. Chinese culture transforms the awe of nature into the obedience to social morality. Nature and human society, therefore to some extent are combined. Nature, in Chinese culture, serves a superior power as God in the West; either individual life or social change is under its charge. Comparing with Western culture, Chinese people tend to accept what nature brings them in order to sustain the harmony with nature; as a result, the attitude to life held by Chinese is relatively passive or even slightly fatalist. Some Chinese proverbs may reflect or refract this sort of attitude:

谋事在人，成事在天

人算不如天算。

命里有时终须有, 命里无时莫强求。

有福不用忙, 无福跑断肠。

守命安分, 顺时听天。

Because of the nonmechanistic view toward nature, Chinese culture places emphasis on the intuitive wisdom. According to Fisher and Luyster (1991), the Eastern view including that of Chinese maintains that "intuition transcends 
the data of the senses and the manipulation of the mind to perceive truths that seems to lie beyond reason" (qtd. in Samovar et al., 2000, p. 104). The Chinese proverbs “只可意会不可言传” and “书不尽言, 言不尽意” refract the significance of intuition in gaining knowledge.

The view of taking humankind and nature as a unity make Chinese adopt a holistic thinking pattern; Chinese take the world as a unit—aspects from the tiniest details to grandest features are linked with each other, e.g. in “牵一发而动全 身”. Chinese culture stresses the connection within the world. Chinese view events in connection to the totality and "middle values are articulated and a reciprocal relationship between the two extremes is emphasized" (ibid, p. 129). Folk idioms such as “物极必反”, “乐极生悲”, “福祸相依” all reflect Chinese holistic thinking of the world. Some popular proverbs including “三十年河东，三十年河西”, “分久必合，合久必分”refract that even the opposite extremes are close connected to each other and may exchange their position in some conditions.

\section{B. Social Proverbs about Social Relationship}

Relational Orientation is about how people perceive their relationships with others. The relational orientations on the continuum range from authoritarianism via collectivism to individualism. (ibid, p. 78-79) Cultures holding authoritarianism as their view towards social relationship believe that some people are born superior to others. Collective cultures consider the group as the most important unit of social entities. Groups have priority over individuals. Cultures valuing individualism believe every member of a society should have equal rights. Hofstede (1991) offers four value dimensions, among which the individualism-collectivism may be the most influential. "Hofstede's work was one of the earliest attempts to use extensive statistical data to examine cultural values." (Samovar et al., 2000, p. 66) According to Hofstede's (1991) statistics, English spoken countries including the United States, Australia, Great Britain, Canada, New Zealand as well as many European nations tend towards individualism. Trandis (1990) estimates that "about $70 \%$ of the population of the world lives in collective cultures" (qtd. in Samovar et al., 2000, p. 68). Although no information of mainland China has been provided, Taiwan and Hong Kong whose dominant culture is also Chinese culture ranks among top countries or regions valuing collectivism. (Hofstede, 1991)

1. English Social Proverbs about Individualism

Individualism refers to "the doctrine, spelled out in detail by the seventeenth-century English philosopher John Locke, that each individual is unique, special, completely different from all other individuals, and 'the basic unit of nature"'(Samovar et al., 2000, p. 62). As the basic unit of nature or society, the uniqueness of individual is considered to have the highest value in cultures promoting individualism. In those cultures, values, rights, and duties originate from individualism; an "I" consciousness is widespread. (ibid, p. 68) Personal achievements supersede group ones; members have no tendency to feel dependent on organizations and institutions; individuals have the right to their liberty, private property, unique thoughts, etc; competition instead of cooperation is preferred and individual initiative and decision making are encouraged.

Individualism has a long history in Western culture. It can be traced to the democracy in ancient Greek city-states. Christianity as the dominant religion in the West also contributes in an important way to the prevailing individualism in Western culture. In Christian doctrines, God has a special relationship with every man in which God sees and hears, rewards and punishes. Everyone is important to God. Western culture values most the individual; individualism is at the heart of Western culture. Groups should not sacrifice individual freedom, rights and happiness to their development; they are on and for individuals; the freedom and development of individuals is the ultimate destination of any society. Any group is merely means for individuals to fulfill their aims; the loyalty of individuals to groups is weak and individuals are apt to change membership for their own need. Many English proverbs reflect or refract individualism. "Pull yourself up by your own boot straps" emphasizes the individual initiative. "Do your own things" and "he is only bright that shines by himself" stress the self-independence. The proverb "God helps those who help themselves" also puts emphasis on individual initiative and self-independence. The proverb "a man's home is his castle" uses "castle" as a metaphor to describe the exclusive nature of home as one's territory and refracts the privacy valued in Western culture. The proverb "a man may well bring a horse to the water, but he cannot make him drink" requires people to respect individual decision and freedom. Many English proverbs reflecting individualism can be found:

Every man should take his own.

Every man is a king in his own home.

He who depends on another dines ill and sups worse.

It is the squeaky wheel that gets the oil.

Self comes first.

Equality is closely linked to individualism. In Christianity, everyone is created equal. The concept of covenant permeates the Holy Bible. Covenant means both rights and duties. Everyone has the right to be chosen by God if he fulfills the duties God expects; in turn God will protect the chosen people. Everyone whoever he or she is will get the Last Judgment. Behind the belief in all-mighty God, a value of equality prevails. In Western culture, all have a right to pursuit happiness and succeed regardless of their backgrounds, sexes, or races. The society should also equal opportunities to ensure the right. The value of equality is widespread in both the relationship within families and that among friends and colleagues. It is taken as one of the basic principles of people's behaviour. Many English proverbs reflect or refract equality. The proverb "all men are brothers" uses the word "brother" to indicate the close and equal 
relationship among people. The proverbs "all things in their being are good for something" and "everything is good for something" refract the value on equality by literally taking everything as a useful thing. "Great men are not always wise" refracts the negative attitude of Western culture towards hierarchy or authority. Other proverbs about equality are as follows:

A cat may look at a King.

Jack is as good as his master.

Six feet of earth make all men equal.

The best charity is justice to all.

We are all Adam's children.

As a result of individualism and the high mobility in society, Western culture stresses the competition among individuals. In cultures highly valuing individualism, people take the initiative in advancing personal interests and behave assertively and aggressively in interacting with others. The competitive nature is encouraged from the early childhood; open confrontation and even some abrasiveness can be tolerated or expected. Children get less support in cultures fostering individualism; they must learn quickly to be independent and courage. The proverb "a horse never runs so fast as when he has other horses to catch up and outpace" refracts the value of competition. The word "outpace" contains the information that men should try to succeed others. "Better be envied than pitied" also refracts the encouragement to competitive nature and aggressive behaviour in Western culture; the word "envy" indicates that people should try to lead a better life than others. Many other English proverbs valuing competition can be found:

He that looks not before, finds himself behind.

He who does not advance loses ground.

2. Chinese Social Proverbs about Collectivism

Triandis gives a definition for collectivism that collectivism puts greater emphasis on the requirements and achievements of groups rather than individuals, social norms and duty given by the group instead of behaviour to pursue pleasure, beliefs shared among group members rather than that highlighting individual uniqueness, and readiness to cooperate with in-group members. (see in Samovar et al., 2000)

In collective societies, there is a clear line between those in and out of a particular group. People depend on their groups like extended families or clans to get support and protection, and in turn they owe loyalty to the groups. Comparing with the "I" consciousness above, a "we" consciousness prevails in collective cultures. (ibid) Groups invade private life; individuals attain their identity from their groups; they feel belonging to and emotionally dependent on organizations or institutions. Other behaviour such as indirect ways of communication, concern for others, cooperation are intimately linked to collectivism and can be observed easily in collective cultures.

As mentioned above, the foundation of Chinese civilization is agriculture. Generations of Chinese peasants were tied to the land on which they lived and worked. Little mobility was made, socially or geographically, by Chinese peasants except for the wartime and famine. The agrarian lifestyle of living and working stably together for thousands of years partially makes Chinese value collectivism. Collectivism has a long history in China; Confucianism, with its principal role in Chinese society, strengthens collectivism and makes it the mainstream in Chinese culture. In Confucianism, individuals rely on groups; only with the help of group can individuals defend their interests and fulfill their value. Responsibilities and duties of individuals towards groups are emphasized in Chinese culture. The relationship among Chinese people is mutual-dependence and mutual-trust. “中国文化中的自我是依存的自我, 而西方文化中的自我是 独立的自我 (the self in Chinese culture is interdependent self, while in Western culture the independent self).” (胡文 仲, 1995, p. 248) Many Chinese proverbs straight reflect or indirectly refract the orientation of collectivism. The proverb winning high popularity that “三个臭皮匠，顶个诸葛亮”, employing a remarkable metaphor of a well-known historical figure, emphasis the collective strength. Some other Chinese social proverbs about collectivism are as follows:

双拳难敌四手, 好汉架不住人多。

一家不够, 百家相凑。

孤雁难飞, 孤掌难鸣。

一人不成阵, 独木不成林。

一人计短, 百人计长。

众人一条心, 黄土变成金。

一个篱笆三个桩, 一个好汉三个帮。

In this kind of collective culture, the uniqueness of individual and aggressive behaviour can hardly be valued; on the contrary, individuals tend to satisfy the need and principles of groups in order to protect his membership and avoid conflicts with others. The proverb “枪打出头鸟” refracts Chinese culture's objection to individual uniqueness and put emphasis on the principle of mean as an effective way to coexist with others. People conduct their behaviour according to social morality in order to own and maintain interpersonal harmony. Chen and Xiao (1993) suppose that "it is without a doubt that harmony is one of the primordial values of Confucianism and of the Chinese culture." (qtd. in Samovar et al., 2000, p. 84) Confucianism takes harmony as the final goal of man's behaviour, because it can lead people to pursue a conflict-free and group-oriented human relationship. The proverb “天时不如地利, 地利不如人和” shows the 
foremost importance of harmonious interpersonal relationship in Chinese culture. Chinese families maintain and transmit this value by teaching children social skills for group togetherness, respecting others, and interdependence in relationship. Many Chinese proverbs reflect the pursuit for interpersonal harmony:

君子成人之美，不成人之恶。

己所不欲, 勿施于人。

得饶人处且饶人。

忍一时风平浪静, 退一步海阔天空。

不看僧面看佛面。

冤家宜解不宜结。

Confucius uses a famous sentence “君君，臣臣，父父，子子 (king is king; subject is subject; father is father)” to stress the hierarchy in Chinese society. Hierarchy minimizes the mobility and alteration of China so that to stabilize this collective society. China has undergone around 2000 years of feudalism and the concept of hierarchy has permeated into every corner of Chinese culture. The proverb “吃得苦中苦，方为人上人” literally asks people to be industrious and work hard, but the part “人上人” refract the view of hierarchy. The word “上” indicates that people are organized into a system with ranks or levels from the lowest to highest. People are judged according to their social status or “importance” to society; some are superior to the rest. The proverbs “鸡蛋碰不过石头” and “胳膊拧不过大腿” metaphorically implie the different levels of importance of different things or persons in society. Many Chinese proverbs convey the view of hierarchy:

力微休负重, 言轻莫劝人。
大鱼吃小鱼, 小鱼吃虾米。
官大一级压死人。
宰相家人七品官。

\section{Social Proverbs about Time Orientation}

Cultures vary greatly in the conceptions of time. Some cultures value the future and the present while others stress the past. Future-oriented cultures emphasize the future and expect it to be grander and nicer than the present; present-oriented cultures hold that the moment is of the most significance and enjoyment comes in the present; past-oriented cultures believe in the significance of prior events and the past such as history, established religions, and traditions serves as the guide for making decisions and determining the truth. (ibid, p. 77) In Hofstede's Value Dimensions, uncertainty avoidance is linked with people's conceptions of time. Based on the truism that the future is unknown, uncertainty avoidance refers to "the extent to which a culture feels threatened by anxious about uncertain and ambiguous situations" (ibid, p. 69).

1. English Social Proverbs about Valuing the Future

Western culture values the present and the future, especially the future. Because the future is where the happiness is, Western culture places importance on change and progress. English proverb "expectation is better than realization" reflects the beauty of the future. The proverb "new things are fair" uses a praise for new things to imply people's admiration on the future than the past. In the proverb "a wise man changes his mind, a fool never", the importance on change is obvious. "A constant guest is never welcome" uses an experience in life to refract the avoidance of static situation in Western culture. Many English proverbs directly reflect the value on the future and change:

Newer is truer.

Change brings life and Variety is the spice of life.

This value produces a wide range of behaviour patterns such as optimism, taking risks, etc. In terms of Hofstede's (1991) Dimensions, cultures valuing the future have a low-uncertainty-avoidance need. These cultures accept the uncertainty in life more easily; they are more flexible so that they are willing to take risks and tolerate the unusual. "Come what may, heaven won't fall" refracts a dare to take challenges and enter into unknown territories. "Fear not the future; weep not for the past" straightforwardly reflects westerners' value on the future rather than the past. Some other English proverbs are also about such values:

All is not lost that's in peril.

He who risks nothing gain nothing.

Western culture prefers youth because the youth stands for the future. In the proverb "age is honorable and youth is noble", both the elderly and youth are valued literally; but the word "noble" indicates the premier quality of youth.

2. Chinese Social Proverbs about Valuing the Past

Chinese culture respects the past. "Each Chinese derives his or her strongest sense of identity from history." (Samovar et al., 2000, p. 116) Chinese worship ancestors, ancient great figures as well as those classics; they respect the previous experience and promote traditional morality. Chinese tend to judge surroundings with the criteria established and handed down from the predecessors. The idiom “人心不古” directly uses the word “古” to refer to merits. Many Chinese proverbs reflect or refract the value on the past. “前事不忘, 后事之师” emphasizes the importance of the past as the teacher of present life. The famous maxim and subsequently popular proverb by Confucius “温故而知新” 
stresses the past by suggesting that the new knowledge is not gained by discoveries but reflection on the past. “不听老 人言，吃亏在眼前” highlights the experience achieved in ancient times through kind of warning.

Cultures stressing the past avoid uncertainty; they prefer stable life and are not willing to take risks; they rather maintain the traditional customs and tolerate the current difficulties than make any changes. Many Chinese proverbs reveal this tendency. The proverb “知足者常乐, 能忍者自安”, by advising people to be content of the present life state, prevents its addressees from alterations. The high-uncertainty-avoidance can raise a passive view on taking risks. Proverbs “不求有功但求无过”, “宁走十步远, 不走一步险” and “小心驶得万年船” reflect or refract the negative attitude towards risks.

Valuing the past determines Chinese to respect the elderly, because to some extent they are ancestors around us and stand for the past. “姜还是老的辣” metaphorically put emphasis on the elderly and previous experience. Filial piety is highly valued in Chinese culture. “慈母手中线, 游子身上衣” literally describe the moving love of a mother to her son far away but actually refract the filial piety by reminding people of their close and forever link with their parents and the responsibility to them. Many Chinese proverbs reflect this merit:

父母在, 不远游。

十恶淫为首, 百善孝为先。

千里烧香，不如在家敬爹娘。

谁言寸草心，报得三春晖。

\section{CONCLUSION}

Proverbs are idiomatic expressions on sentence level which are culture-bounded. Social proverbs contain life philosophies and experience as well as moral standards; aspects of social life are reflected in the mirror of social proverbs. The deep structures of Western and Chinese cultures, which show sharp distinction, are reflected or refracted in corresponding social proverbs.

There are inevitably limitations and defects in this study; accordingly, some improvements should be made in further researches. English and Chinese social proverbs have not been studied comprehensively in this study. The proverbs selected for the case study are limited in number and some of them may lack typicality. A thorough investigation into social proverbs as well as quantitative research methods may need in future studies to ensure the validity and reliability of the results. The author's inadequate ability may make the interpretation in the case study superficial; extensive reading on relevant issues of Western and Chinese cultures is required in future researches.

\section{REFERENCES}

[1] Bates, D. G. \& F. Plog. (1976). Cultural Anthropology ( $\left.3^{\text {rd }}\right)$. New York: McGraw-Hill.

[2] Edgar, A. \& Sedgwick, P. (eds.) (2008). Cultural Theory: The Key Concepts ( $\left.2^{\text {nd }}\right)$. London \& New York: Routledge.

[3] Gu, Jiazu \& Lu, Sheng. (ed.) (1990). Language and Culture. Shanghai: Shanghai Foreign Language Education Press.

[4] Hanks, P. (ed.) (1979). Collins Dictionary of the English Language. London: Collins.

[5] Hofstede, G. (1991). Cultures and Organizations: Software of the Mind. London: McGraw-Hill.

[6] Honeck, R. P. (1997). A Proverb in Mind: A Cognitive Science of Proverbial Wit and Wisdom. New Jersey: Lawrence Erlbaum.

[7] Hu, Wenzhong. (1995). Anglo-American Culture Dictionary. Beijing: Foreign Language Teaching and Research Press.

[8] Institute of Linguistics of the Chinese Academy of Social Sciences. (ed.) (1992). Modern Chinese Dictionary. Beijing: The Commercial Press.

[9] Kluckhohn, F. R. \& Strodtbeck, F. L. (1960). Variations in Value Orientaions. New York: Row \& Peterson.

[10] Kramsch, C. Language and Culture. (2000). Shanghai: Shanghai Foreign Languages Education Press.

[11] Mieder, W. (1989). American Proverbs: A Study of Texts and Contexts. New York: Peter Lang.

[12] Paden,W. E. (1994). Religious Worlds: The Comparative Study of Religion. Boston \& Massachusetts: Beacon.

[13] Rokeach, M. (1973). The Nature of Human Values. New York: Free Press.

[14] Samovar, L. A. et al. (2000). Communication between Cultures $\left(3^{\text {rd }}\right)$. Beijing: Foreign Language Teaching and Research Press.

[15] Simpson, J. \& Speake, J. (eds.) (2001). Oxford Concise Dictionary of Proverbs. Shanghai: Shanghai Foreign Languages Education Press.

[16] Stevenson, B. (ed.) (1976). The Macmillan Book of Proverbs, Maxims, and Famous Phrases. New York: Macmillan.

[17] Watson, O. (ed.) (1976). Longman Modern English Dictionary. London: Longman.

[18] Wang, Dechun et al. (2003). Chinese-English Proverbs and Culture. Shanghai: Shanghai Foreign Language Education Press.

[19] Webster, N. (ed.) (1979). Webster's Dictionary of the English Language, Unabridged. New York: Publishers International Press.

[20] Weinberg, H. L. (1959). Levels of Knowing and Existence. New York: Harper \& Row.

[21] Wen, Duanzheng. (2005). Chinese Lexicology. Beijing: The Commercial Press.

[22] Wen Duanzheng. (1985). Proverbs. Beijing: The Commercial Press.

[23] Whiting, B. J. (1989). Modern Proverbs and Proverbial Sayings. Cambridge, Massachusetts \& London: Harvard University Press.

[24] Wilson, F. P. (ed.) (1982). The Oxford Dictionary of English Proverbs ( $\left.{ }^{\text {rd }}\right)$. Oxford: Oxford University Press.

[25] Word-Ocean Dictionary Editor Committee. (ed.) (1979). Word-Ocean Dictionary. Shanghai: Shanghai Lexicographical Publishing House.

[26] Zen, Zili. (1983). Summary of English Proverbs. Beijing: The Commercial Press. 
Wen Zhao, (Han Zu) 28, is a lecturer teaching English language in English department of Sichuan Agricultural University. He attained his MA degree of Foreign and Applied Linguistics in Sichuan University in China. He has interests in Cognitive Linguistics and Culture Study. 